Mark A. Singleton MD, Judith I. Rosen BA, Dennis M. Fisher MD

\title{
Plasma concentrations of fentanyl in infants, children and adults
}

To evaluate whether there are age-related differences in the plasma concentration-vs-time course of fentanyl, the authors administered fentanyl to seven infants (3-10 months), seven children (1-9 years) and seven adults (18-4l years). Anaesthesia was induced with thiopentone, nitrous oxide, and pancuronium; following tracheal intubation, fentanyl (approximately $30 \mu \mathrm{g} \cdot \mathrm{kg}^{-1}$ for infants and children, $20 \mu \mathrm{g} \cdot \mathrm{kg}^{-1}$ for adults) was administered as a 2-min IV infusion. Ancesthesia was mainrained with nitrous oxide, pancuronium, and morphine sulphate as clinically indicated. Plasma samples were abtained for $4 \mathrm{~h}$ and fentanyl concentrations determined by radisinmunoassay. Plusma concentrations per $\mu \mathrm{g} \cdot \mathrm{kg}^{-1}$ fentanyl administered were lowest in infants 4-10 and 60-240 min after the start of the 2-min infusion; values for children were lower than those for adults 4,180 and $210 \mathrm{~min}$ after the start of the 2-min infusion. These findings are consistent with the authors' clinical observation that infants tolerate larger doses of fentanyl than do adults.

\section{Key words}

ANALGESICS: fentanyl; ANAESTHESIA: paediatric.

From the Department of Anesthesia, University of Califomia. San Francisco, Califomia.

Address correspondence 10: Dr. D.M. Fisher, Deparment of Anesthesia, Box 0648, University of California, San Francisco, California 94143

Dr. Fisher is the recipient of a New Investigator Award from the National Institutes of Health. Materials for the fentanyl assay were supplied by Janssen Pharmaceutica.
We have administered large doses of fentanyl (ranging from $20 \mu \mathrm{g} \cdot \mathrm{kg}^{-1}$ for procedures lasting $75-90 \mathrm{~min}$ to $50-70 \mu \mathrm{g} \cdot \mathrm{kg}^{-1}$ for procedures lasting $4-6 \mathrm{~h}$ ) to infants and found end-tidal or arterial $\mathrm{PCO}_{2}$ to be normal in the immediate postoperative period, without the administration of narcotic antagonists (unpublished observations). In contrast, adults given comparable doses of fentanyl for surgery of these durations have elevation of their arterial $\mathrm{PCO}_{2}$ or marked depression of their ventilatory response to carbon dioxide,' and, consequently, may require postoperative ventilation or narcotic antagonists. This difference between infants and adults might result from maturational changes in respiratury sensitivity to fentanyl. Alternatively, there may be age-related changes in distribution (volume of distribution) or elimination (clearance) which might result in lower plasma concentrations of fentanyl in infants. To determine whether there are age-related differences in plasma concentrations, we determined its plasma concentration-vs-time course in infants, children and adults.

\section{Methods}

Following approval from our committee on human studies, we obtained informed consent to study patients scheduled for elective noncardiac surgery. Patients were divided by age into three groups: infants $(3-10(6.5 \pm 2.8$, mean \pm SD) months, $\mathrm{n}=7)$, children ( $\mathrm{I}-9(2.7 \pm 2.8)$ ycars, $\mathbf{n}=7)$, and adults $(18-41(33.1 \pm 8.3)$ years, $n=7)$. Patients were ASA physical status I or II, were free of hepatic or renal disease and underwent nonabdominal surgery. No premedication was given. Anaesthesia was induced with thiopentone, $3-6 \mathrm{mg} \cdot \mathrm{kg}^{-1} \mathrm{IV}$, nitrous oxide and oxygen. Pancuronium, $0.1 \mathrm{mg} \cdot \mathrm{kg}^{-1}$, was given to facilitate tracheal intubation. Fentanyl was administered as a 2 -min constant infusion into a peripheral vein. The doses were $31.2 \pm 1.5,30.8 \pm 0.6$, and $20.7 \pm 1.3 \mu \mathrm{g}$. $\mathrm{kg}^{-1}$ (mean \pm SD) for infants, children and adults, respectively. We administered a larger dose to paediatric patients because our clinical observations suggested that this larger dose would result in comparable plasma concentrations at the end of the four-hour sampling period. Anaesthesia was maintained with nitrous oxide, oxygen, pancuronium and morphine sulphate, as clinically indicated. Ventilation was controlled to maintain normocar- 


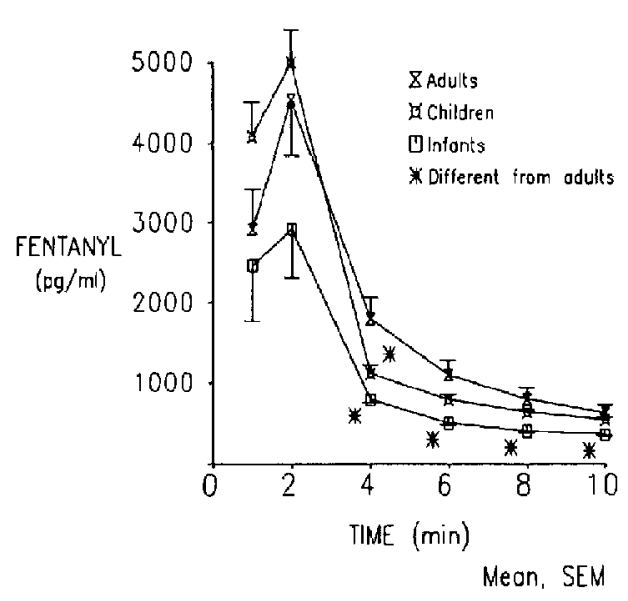

FIGURE 1 Fentanyl concentrations per $\mu \mathrm{g} \cdot \mathrm{kg}^{-1}$ administered for the first $10 \mathrm{~min}$ after the beginning of the $2-\mathrm{min}$ infusion are plotted against time.

bia (end-tidal $\mathrm{PCO}_{2}$ ranging from $30-35 \mathrm{mmHg}$ ). Potent inhaled anaesthetics were not used because they decrease hepatic blood flow ${ }^{2}$ and therefore may alter the clearance of fentanyl.

Heparinized blood samples were obtained from arterial catheters, except in one infant and five children from whom central venous samples were obtained. Samples were obtained prior to and at $1,2,4,6,8,10,15,20$, $25,30,45,60,90,120,150,180,210$, and $240 \mathrm{~min}$ after the beginning of the infusion. Plasma was stored at $-20^{\circ} \mathrm{C}$ until fentanyl concentrations could be determined by radioimmunoassay. ${ }^{3,4}$ The assay is sensitive to 0.5 $\mathrm{ng} \cdot \mathrm{ml}^{-1},{ }^{5}$ with a coefficient of variation of ten per cent at a concentration of $1.0 \mathrm{ng} \cdot \mathrm{ml}^{-1}$.

Plasma fentanyl concentration for each subject at each sampling time was divided by the dose received by that subject; mean values for each group were compared using analysis of variance and the Student-NewmanKeuls test. ${ }^{6}$ For all comparisons, $\mathrm{p}<0.05$ was considered significant.

\section{Results}

Fentanyl concentrations per $\mu \mathrm{g} \cdot \mathrm{kg}^{-1}$ administered were lower in infants than in adults $4-10$ and $60-240 \mathrm{~min}$ after the start of the 2-min infusion (Figures 1 and 2); values for infants were lower than those for children, $60-150,210$ and $240 \mathrm{~min}$ after the start of the infusion. Values for children were lower than those for adults 4 , 180 and 210 min after the start of the infusion. Second- ary peaks in plasma fentanyl concentration* were observed in approximately half of the patients in each group. These transient increases in plasma fentanyl concentration generally occurred between 180 and $240 \mathrm{~min}$ following fentanyl administration.

\section{Discussion}

Throughout much of the four-hour period following administration of comparable doses per kilogram, plasma fentanyl concentrations are lower in infants than in children or adults. These lower concentrations in infants would result from age-related changes in either, or both, distribution or elimination.

The finding that fentanyl concentrations are lower in infants shortly after the infusion suggests a larger distribution volume in these patients. Because fentanyl is a lipophilic drug, the volume into which it distributes depends upon the relative proportion and constituency of body fat. The fullterm newborn has an average lipid composition of approximately 12 per cent, which increases rapidly during the neonatal period ${ }^{7}$ At one year of age, lipid content averages 28-30 per cent of body weight, and, as children develop muscular tissue, lipid, as a per cent of body weight, declines. After puberty, there is a gradual increase in body lipid content which continues throughout life. Because of these maturational changes in lipid content, we expected volume of distribution to increase with age. However, there is another factor which affects volume of distribution, the fraction of drug in plasma which can equilibrate with other tissues, i.e., the fraction that is not protein bound. For

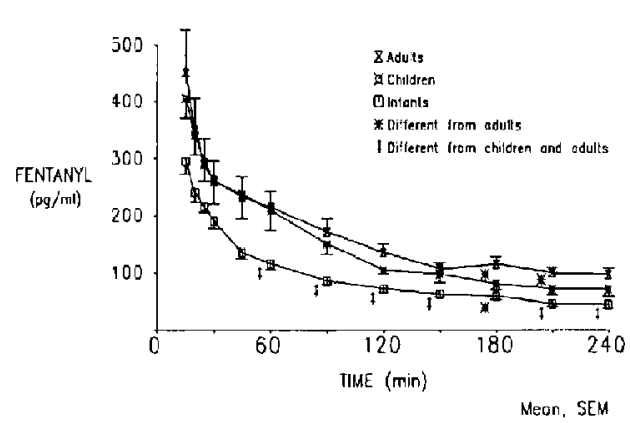

FIGURE 2 Fentanyl concentrations per $\mu \mathrm{g} \cdot \mathrm{kg}^{-1}$ administered for the remainder of the $4 \mathrm{~h}$ sampling period are plotted against time.

* We defined a secondary peak as a greater than ten per cent increase in plasma fentanyl concentration during elimination which was observed in two or more successive measurements. 
many drugs, plasma protein binding is lower in young patients than in adults ${ }^{8}$ which would increase volume of distribution in infants. Although the age-related changes in the fraction of fentanyl bound to plasma proteins have not been determined, we speculate that differences in protein binding might explain the lower initial concentrations in infants.

The finding that fentanyl concentrations remain lower in infants throughout much of the four-hour sampling period suggests that clearance is higher in these subjects. Because fentanyl is eliminated in the liver, two factors, the fraction of fentanyl cleared during each pass through the liver, and hepatic blood flow, infuence its total clearance. In adults, ${ }^{9}$ nearly all the fentanyl entering the liver is eliminated, by mixed-function oxidase enzymes. ${ }^{10} \mathrm{Al}$ though little is known about age-related changes in the activity of these enzymes in humans, studies in animals suggest that levels in infants and children are comparable to those in adults. ${ }^{11}$ Thus, in infants and children, enzyme activity should not limit the clearance of fentanyl

The second factor affecting the clearance of fentanyl is hepatic blood flow. Although developmental changes in hepatic blood flow in humans have not been measured, the liver represents a larger portion of total body mass in infants (five per cent) compared to adults (two per cent). ${ }^{12}$ Because cardiac output is higher in infants than in adults, ${ }^{13}$ it is likely that liver blood flow per $\mathrm{kg}$ of body weight is greater in infants. This would result in a larger pcrcentage of the fentanyl in the central compartment being delivered to the liver during each circulation. Consequently, clearance should be greatest in infants, while values for children should approach those for adults. Johnson et $a l^{14}$ determined the pharmacokinetics of fentanyl in infants, children and adults anaesthetized with potent inhaled anaesthetics and found plasma clearance to be markedly greater in infants than in children or adults $\left(18.1 \pm 1.4,11.5 \pm 4.2\right.$, and $10.0 \pm 1.7 \mathrm{ml} \cdot \mathrm{kg}^{-1} \cdot \mathrm{min}^{-1}$, respectively). Our finding that plasma concentrations are lower in infants is consistent with the greater plasma clearance reported by Johnson et al. ${ }^{14}$

In approximately half our subjects, we observed transient increases in the plasma concentration of fentanyl during the elimination phase. These peaks may result from fentanyl sequestered in the muscle being released to plasma; this release would occur during recovery from anaesthesia when spontaneous movement increases muscle perfusion. ${ }^{15}$ The clinical importance of these secondary peaks has not been evaluated; however, they may be the cause of delayed episodes of respiratory depression. ${ }^{10}$

Because we sampled plasma for only $4 \mathrm{~h}$ following the administration of fentanyl, the presence of secondary peaks during elimination limited our ability to determine the elimination half-life of fentanyl in these subjects. Consequently, we were unable to determine the pharmacokinetics of fentanyl. Our decision to sample for only $4 \mathrm{~h}$ was based on our expectation that, in infants, plasma fentanyl concentration would fall below the sensitivity of the assay in samples obtained after $4 \mathrm{~h}$. The use of a more sensitive assay technique, such as gas chromatography, was prohibited by the limited quantity of blood that one can sample from infants.

In conclusion, we found that plasma fentanyl concentrations were lower in infants throughout much of the four-hour sampling period. These findings are consistent with our clinical impression that these patients tolerate large doses of fentanyl during lengthy surgical procedures without developing postoperative respiratory depression.

\section{References}

1 Cartwright P, Prys-Roberts C, Gill K, Dye A, Stafford M, Gray $A$. Ventilatory depression related to plasma fentanyl concentrations during and after anesthesia in humans. Anesth Analg 1983; 62: 966-74.

2 Gelman $S$, Fowler $K C$, Smith LR. Liver circulation and function during isoflurane and halothane anesthesia. Anesthesiology 1984; 61: 726-30.

3 Henderson GL, Frincke J, Leung CY, Torten M, Benjamini E. Antibodies to fentanyl. J Pharmacol Exp Theor 1975; 192: 489-96.

4 Schünler J, White PF. Optimization of the radioimmunoassays for measuring fentanyl and alfentanil in human serum. Anesthesiology 1984; 61: 315-20.

5 Rodhard D. Statistical estimation of the minimal detect able concentration ("sensitivity") for radioligand assays Anal Biochem 1978; 90: 1-12.

$6 \mathrm{Zar} J H$. Biostatistical Analysis. Englewood Cliffs: Prentice-Hall, 1974; 133-7, 151-8.

7 Frits-Hansen $B$. Body composition during growth. In-vivo measurements and biochernical data correlated to differential anatomical growth. Pediatrics 1971; 47: 264-74.

8 Ehrnebo $M$, Agurell S, Jalling B Boreus LO. Age differences in dng binding by plasma proteins: Studies on human foctuses, neonates and adults. Eur J Clin Pharmacol 1971; 3: $189-93$.

9 Bower $S$, Hull CJ. The comparative pharmacokinetics of fentanyl and alfentanil. Br J Anaesth 1982; 54: 871-7.

10 Goromaru $T$, Matsuura $H$, Yoshimura $N$ et al. Identification and quantitative determination of fentanyl mctabolites in patients by gas chromatography-mass spectrometry. Anesthesiology 1984; 61: 73-7.

11 Short CR, Maines MD, Westfall BA. Postnatal development of drug-metabolizing enzyme activity in liver and 
extra-hepatic tissues of swine. Biol Neonate 1972; 21: 54-68.

12 Nayak NC, Ramalingaswami V. Normal structure. In: Chandra $\mathbf{R K}_{1}$ ed. The liver and biliary system in infants and children. Edinburgh: Churchill Livingstone, 1979: 1-17.

13 Rudolph AM. Fetal circulation and cardiovascular adjustments after birth. In: Rudolph AM, Hoffman JIE, eds. Pediatrics, 17th Edition. Norwalk. Connecticut: AppletonCentury-Crofts, 1982: 1231-5.

14 Johnson KL, Erickson JP, Holley FO, Scott JC. Fentanyl pharmacokinetics in the pediatric population (abstract). Anesthesiology 1984; 61: A441.

15 Hudson. RJ. Thomson IR, Cannon JE. Friesen RM. Meatherall RC. Pharmacokinetics of fentanyl in patients undergoing abdominal aortic surgery. Ancsthesiology 1986; 64: 334-8.

16 Becker LD. Pauison BA, Miller RD, Severinghaus JW, Eger EI II. Biphasic respiratory depression after fentanyldroperidol or fentanyl alone used to supplement nitrous oxide anesthesia. Anesthesiology 1976; 44: 291-6.

\section{Résumé}

Afin d'évaluer s'il existe des différences reliées à l'age dans la concentration plasmatique versus temps du fentanyi, les auteurs ont administré du fentanyl à sept nourissons (3-10 mois), sept enfants ( $1-9$ ans) et sept adultes ( $18-41$ ans). L'induction de l'anesthésie s'est faite par administration de thiopentone. protoxyde d'azote et pancuronium. Après l'intubation endo. trachéale, du fentanyl (approximativement $30 \mu \mathrm{g} \cdot \mathrm{kg}^{-1}$ pour les nourissons et enfants, $20 \mu \mathrm{g}^{\mathrm{kg}}{ }^{-1}$ pour les adultes) a été administré en deux minutes par infusion intraveineuse. L'anesthésie érait maintenue avec le protoxyde d'azote, pancuromium et stilfate de morphine selon la clinique. Les échantillons plasmatiques élaient abtenus pour quatre heures et les concentrations de fentanyl déterminées par radioimmunoessay. Les concentrations plasmatiques par $\mu \mathrm{g} \cdot \mathrm{kg}^{-1}$ de fentanyl administrées etaient plus basses chez les nourissons à 4-10,60-240 minutes après le débul de la perfusion. Les valeurs pour les enfants etaient plus basses que celles de l'adulte 4,180 et 210 minures après le début de la perfusion. Ces résultats sont consistants avec l'observation clinique des auteurs à l'effet que les nouris sons tolèrent des doses plus grandes de fentanyl que les adultes. 